\title{
Analisis Pengaruh Kualitas Pelayanan terhadap Kepuasan Konsumen pada Depot Air Minum Isi Ulang Tirta Tamiang di Kecamatan Tenggulun
}

\author{
Safrizal \\ Fakultas Ekonomi, Universitas Samudra \\ e-mail: safrizal@unsam.ac.id
}

\begin{abstract}
Abstrak
Penelitian ini bertujuan: (1) Untuk mengetahui pengaruh kualitas pelayanan (bukti fisik, keandalan, daya tanggap, jaminan dan perhatian) secara parsial terhadap kepuasan konsumen pada depot air minum isi ulang Tirta Tamiang di Kecamatan Tenggulun. (2) Untuk mengetahui pengaruh kualitas pelayanan (bukti fisik, keandalan, daya tanggap, jaminan dan perhatian) secara simultan terhadap kepuasan konsumen pada depot air minum isi ulang Tirta Tamiang di Kecamatan Tenggulun. Populasi dalam penelitian ini adalah konsumen air isi ulang berdasarkan catatan pihak depot air minum isi ulang Tirta Tamiang dari Januari 2016 sampai Desember 2016 yang jumlahnya 936 konsumen. Hasil analisis data yaitu $K K=2,193+0,065 B F+0,166 K+0,032 D T+0,075 \mathrm{~J}+0,164 E$. Koefisien determinasi (Adjusted $R$ Square) yaitu 0,219. Artinya, bukti fisik, keandalan, daya tanggap, jaminan, dan empati mempengaruhi kepuasan konsumen pada depot air minum isi ulang Tirta Tamiang sebesar 21,9\%.
\end{abstract}

Kata Kunci: Bukti Fisik, Keandalan, Daya Tanggap, Jaminan, Empati, dan Kepuasan Konsumen

\section{PENDAHULUAN}

Dalam keadaan perekonomian yang semakin sulit ini banyak terjadi persaigan di berbagai bidang kehidupan, termasuk di dalamnya persaingan dalam dunia bisnis. Banyak perusahaan yang saling berlomba untuk mendapatkan pangsa pasar, sehingga hal ini memacu perusahaan untuk berusaha terus maju dalam memperbaiki bisnisnya. Di samping itu dengan adanya kemajuan teknologi, perusahaan dituntut pula untuk dapat mengikuti perkembangan zaman agar tidak tertinggal dengan yang lainnya.

Supaya perusahaan dapat tumbuh dan berkembang dengan baik, maka perusahaan tersebut harus dapat mengantisipasi perkembangan ekonomi yang semakin kompetitif dengan melakukan strategi yang tepat agar tidak tersisih dalam persaingan. Selain itu perusahaan juga harus dapat mengantisipasi kecenderungan ekonomi di masa mendatang dan harus dapat bersaing dengan perusahaan lain yang bergerak di bidang yang sama. Hal itu dilakukan untuk mempertahankan kelangsungan hidup dan kemajuan perusahaan.

Maka pada situasi seperti ini menuntut kejelian pihak perusahaan melihat pergeseran dan perubahan keinginan serta kebutuhan para konsumen membuat perusahaan kewalahan dalam menyusun strategi untuk memenangkan persaingan dalam dunia bisnis yang diakibatkan kemajuan zaman. Dimana kepuasan konsumen sangat diutamakan sehingga dapat memperoleh keuntungan yang diharapkan untuk membiayai kelangsungan operasi perusahaan.

Keadaan pasar yang berlaku kini bukan lagi pasar penjual, tetapi menjadi pasar pembeli dimana penjual yang mencari pembeli. Konsumen dalam hal ini adalah raja yang harus dilayani dengan baik. Secara umum perusahaan menerapkan strategi bisnis kombinasi antara strategi ofensif dan defensif. Dimana strategi ofensif perlu ditujukan untuk meraih atau memperoleh konsumen baru, sedangkan untuk meningkatkan pangsa pasar dan strategi defensif berusaha untuk 
mengurangi kemungkinan customer exit dan beralihnya konsumen dari perusahaan.

Kualitas pelayanan menjadi tuntutan penting dalam persaingan tingkat global, industri dan perusahaan. Tingkat kualitas dinilai berdasarkan sudut pandang konsumen. Untuk menciptakan kualitas layanan tinggi, perusahaan harus menawarkan layanan yang mampu diterima konsumen sesuai atau melebihi harapan konsumen. Dengan adanya kualitas pelayanan yang baik konsumen akan merasa puas dan akan terus melakukan pembelian ulang.

Ada beberapa faktor yang dapat dipertimbangkan oleh konsumen dalam menilai suatu pelayanan yang diberikan oleh perusahaan. Lupiyoadi dan Hamdani (2008), mendefinisikan lima kualitas pelayanan, yaitu: (1) Tangibles atau bukti fisik yaitu penampilan dan kemampuan sarana dan prasarana fisik perusahaan dan keadaan lingkungan sekitarnya. (2) Reliability atau keandalan yaitu kemampuan perusahaan untuk memberikan pelayanan sesuai yang dijanjikan secara akurat dan terpercaya. (3) Responsiveness atau ketanggapan yaitu suatu kemauan untuk membantu dan memberikan pelayanan yang cepat dan tepat kepada konsumen, dengan penyampaian informasi yang jelas. (4) Assurance atau jaminan dan kepastian yaitu pengetahuan, kesopansantunan, dan kemampuan para pegawai perusahaan untuk menumbuhkan rasa percaya para konsumen kepada perusahaan. (5) Empathy atau perhatian yaitu memberikan perhatian yang tulus dan bersifat individual atau pribadi yang diberikan kepada para konsumen dengan berupaya memahami keinginan konsumen.

Dimensi-dimensi inilah yang harus diperhatikan oleh perusahaan dalam memberikan pelayanan kepada konsumen, sehingga berbagai pengalaman yang dapat mengakibatkan kegagalan tidak akan terjadi. Mengingat untuk mendapatkan konsumen baru lebih besar biayanya, dibandingkan dengan pengorbanan dalam mempertahankan konsumen lama. Ini menjadi prioritas utama yang perlu diperhatikan dalam menilai pentingnya kualitas pelayanan suatu perusahaan, adalah sejauh mana pelayanan itu dapat menciptakan tingkat kepuasan semaksimal mungkin bagi konsumen.

Peranan air minum isi ulang semakin besar, hal ini terlihat dengan semakin bertambahnya jumlah air minum isi ulang dimana-mana. Maka persaingan sesama perusahaan air minum isi ulang semakin tajam. Peningkatan penduduk yang dibarengi dengan meningkatnya kebutuhan hidup memberikan lapangan pekerjaan atau bisnis baru. Salah satu contoh bisnis yang mempunyai prospek yang baik adalah bisnis dalam bidang penjualan air minum isi ulang.

Dalam perkembangan ekonomi khususnya saat ini di Kecamatan Tenggulun, merupakan pemekaran dari Kecamatan Kejuruan Muda. Sebagai kecamatan yang baru Kecamatan Tenggulun mengalami perkembangan yang cukup pesat, serta dari tahun ketahun penduduk di Kecamatan Tenggulun semakin meningkat, peningkatan yang terjadi mengkibatkan meningkatnya pula kebutuhan manusia, baik kebutuhan pokok maupun kebutuhan sekunder. Dari mulai kebutuhan akan tempat tinggal, kebutuhan sehari-hari sampai pada kebutuhan tersier semakin hari semakin meningkat.

Tirta Tamiang adalah salah satu depot air minum isi ulang yang berada di Kecamatan Tunggulun yang telah berdiri sejak tahun 2011. Kepuasan konsumen menjadi fokus penting yang harus diperhatikan pemilik depot air minum isi ulang Tirta Tamiang. Berdasarkan penelitian pendahuluan yang dilakukan terhadap 25 konsumen, 20 konsumen pada depot air minum isi ulang Tirta Tamiang di Kecamatan Tenggulun menyatakan bahwa permasalahan dari segi bukti fisik adalah alat cuci galon dan mesin pengisian air yang digunakan masih sederhana, dari segi keandalan lamanya petugas mengantar air minum ke rumah konsumen, dari segi daya tanggap adalah tidak adanya sarana komunikasi yang memadai, dari segi jaminan kurang ramahnya petugas terhadap konsumen dan dari segi perhatian kurangnya perhatian yang diberikan terhadap konsumen. Depot air minum isi ulang Tirta Tamiang Kecamatan Tenggulun mengakui saat ini terjadi penurunan jumlah 
konsumen yang datang langsung untuk membeli.

Adapun tujuan yang ingin dicapai dari penelitian yang dilakukan adalah:

1. Untuk mengetahui pengaruh kualitas pelayanan (bukti fisik, keandalan, daya tanggap, jaminan dan perhatian) secara parsial terhadap kepuasan konsumen pada depot air minum isi ulang Tirta Tamiang di Kecamatan Tenggulun.

2. Untuk mengetahui pengaruh kualitas pelayanan (bukti fisik, keandalan, daya tanggap, jaminan dan perhatian) secara simultan terhadap kepuasan konsumen pada depot air minum isi ulang Tirta Tamiang di Kecamatan Tenggulun.

\section{Pengertian Kualitas Pelayanan}

Menurut Kotler (2005), kualitas adalah keseluruhan ciri-ciri dan karakteristikkarakteristik dari suatu produk atau jasa dalam kemampuannya untuk memenuhi kebutuhan-kebutuhan yang telah ditentukan atau bersifat laten atau tetap. Kualitas merupakan kondisi dinamis yang berhubungan dengan produk, jasa, manusia, proses dan lingkungan yang memenuhi atau melebihi harapan (Tjiptono, 2009).

Kotler (2005) menyatakan pelayanan adalah setiap kegiatan dan manfaat yang dapat diberikan oleh suatu pihak ke pihak lain yang pada dasarnya tidak berwujud dan tidak perlu berakibat pemilikan sesuatu. Menurut Tjiptono (2009), pelayanan meliputi segala macam bentuk penyajian pelayanan, tindakan dan informasi yang diberikan penjual untuk meningkatkan konsumen dalam mewujudkan nilai potensi yang terkandung dalam produk ini yang dibeli konsumen.

Tjiptono (2009) menyatakan bahwa kualitas pelayanan adalah tingkat keunggulan yang diharapkan konsumen dan pengendalian atas tingkat keunggulan tersebut untuk memenuhi keinginan konsumen.

\section{Dimensi Kualitas Pelayanan}

Terdapat lima dimensi kualitas pelayanan menurut Parasuraman dalam Lupiyoadi dan Hamdani (2008), yaitu:

Tangibles atau bukti fisik yaitu
kemampuan

menunjukkan eksistensinya kepada pihak eksternal. Penampilan dan kemampuan sarana dan prasarana fisik perusahaan dan keadaan lingkungan sekitarnya adalah bukti nyata dan pelayanan yang diberikan. Indikator yang dapat diukur dari tangible adalah sebagai berikut:

a. Peralatan dan perlengkapan yang digunakan memadai

b. Fasilitas tempat parkir

c. Karyawan berpenampilan dan berpakaian rapi

d. Sarana komunikasi

5. Reliability atau keandalan yaitu kemampuan perusahaan untuk memberikan pelayanan sesuai yang dijanjikan secara akurat dan terpercaya, pelayanan yang sama untuk semua konsumen tanpa kesalahan. Indikator yang dapat diukur dari reliability adalah sebagai berikut:

a. Kecepatan dan ketepatan waktu dalam pelayanan

b. Kesesuaian janji yang ditawarkan

c. Pemberian palayanan yang tidak membeda-bedakan konsumen

4. Responsiveness atau ketanggapan yaitu suatu kemauan untuk membantu dan memberikan pelayanan yang cepat dan tepat kepada konsumen, dengan penyampaian informasi yang jelas. Indikator yang dapat diukur dari responsiveness adalah sebagai berikut:

a. Pelayanan melalui telpon

b. Kesigapan karyawan dalam menyelesaikan masalah

c. Pemberian hadiah atau kupon kepada konsumen

4. Assurance atau jaminan dan kepastian yaitu pengetahuan, kesopansantunan, dan kemampuan para pegawai perusahaan untuk menumbuhkan rasa percaya para konsumen kepada perusahaan. Terdiri dari beberapa komponen antara lain komunikasi, kredibilitas, keamanan, kompetensi dan sopan santun. Indikator yang dapat diukur dari assurance adalah sebagai berikut:

a. Kesopanan dan keramahan karyawan dalam melayani konsumen 
b. Dapat dipercaya dan memberikan rasa aman

c. Kehandalan dan pengalaman karyawan

4. Empathy atau empati yaitu memberikan perhatian yang tulus dan bersifat individual atau pribadi yang diberikan kepada para konsumen dengan berupaya memahami keinginan konsumen. Indikator yang dapat diukur dari emphaty adalah sebagai berikut:

a. Cepat dan tanggap dalam menyelesaikan keluhan konsumen

b. Memberikan perhatian khusus kepada setiap konsumen

c. Dapat berkomunikasi yang baik dengan konsumen

Menurut Tjiptono dan Chandra (2005), terdapat delapan dimensi kualitas, yaitu:

1. Kinerja (performance) yaitu mengenai karakteristik operasi pokok dari produk inti. Misalnya bentuk dan kemasan yang bagus akan lebih menarik konsumen.

2. Ciri-ciri atau keistimewaan tambahan (features), yaitu karakteristik sekunder atau pelengkap.

3. Keandalan (reliability), yaitu kemungkinan kecil akan mengalami kerusakan atau gagal dipakai.

4. Kesesuaian dengan spesifikasi (conformance to specifications). Yaitu sejauh mana karakteristik desain dan operasi memenuhi standar-standar yang telah ditetapkan sebelumnya. Seperti halnya produk atau jasa yang diterima konsumen harus sesuai bentuk sampai jenisnya dengan kesepakatan bersama.

5. Daya tahan (durability), berkaitan dengan berapa lama produk tersebut dapat terus digunakan. Biasanya konsumen akan merasa puas bila produk yang dibeli tidak pernah rusak.

6. Serviceability, meliputi kecepatan, kompetensi, kenyamanan, mudah direparasi; penanganan keluhan yang memuaskan.

7. Estetika, yaitu daya tarik produk terhadap panca indera. Misalnya kemasan produk dengan warna-warna cerah, kondisi gedung dan lain sebagainya.
8. Kualitas yang dipersepsikan (perceived quality), yaitu citra dan reputasi produk serta tanggung jawab perusahaan terhadapnya.

\section{Pengukuran Kualitas Pelayanan}

Menurut Lupiyoadi (2006), ada lima gap yang dapat terjadi yang menyebabkan adanya perbedaan persepsi mengenai kualitas jasa adalah:

1. Kesenjangan persepsi manajemen.

Yaitu perbedaan antara penilaian pelayanan menurut pengguna jasa dan persepsi manajemen mengenai harapan pengguna jasa. Kesenjangan ini terjadi kurangnya orientasi penelitian pemasaran, pemanfaatan yang tidak memadai atas temuan penelitian, kurangnya interaksi antara pihak manajemen dan konsumen, komunikasi dari atas ke bawah kurang memadai, serta terlalu banyak tingkat manajemen.

2. Kesenjangan spesifikasi kualitas.

Yaitu kesenjangan antara persepsi manajemen mengenai harapan pengguna jasa dan spesifikasi kualitas jasa. Kesenjangan terjadi antara lain karena tidak memadainya komitmen manajemen terhadap kualitas jasa, persepsi mengenai ketidaklayakan, tidak memadainya standarisasi tugas, dan tidak memadainya penyusunan tujuan.

3. Kesenjangan komunikasi pemasaran.

Yaitu kesenjangan antara penyampaian jasa dan komunikasi eksternal.

4. Kesenjangan penyampaian jasa.

Yaitu kesenjangan antara spesifikasi kualitas jasa dan penyampaian jasa (service delivery) kesenjangan ini terutama disebabkan oleh: ambiguitas peran, konflik peran, kesesuaian pegawai dengan tugas yang harus dikerjakan, kesesuaian teknologi yang digunakan pegawai, sistem pengendalian dari atasan yaitu sistem penilaian dan sistem imbalan, perceived control, yaitu sejauhmana pegawai merasakan kebebasan, atau fleksibilitas untuk menentukan cara pelayanan, team work yaitu sejauh mana pegawai dan manajemen merumuskan tujuan bersama. 
5. Kesenjangan dalam pelayanan yang dirasakan.

Yaitu perbedaan presepsi antara jasa yang di rasakan dan yang diharapkan oleh konsumen. Jika keduanya terbukti sama, maka perusahaan akan memperoleh citra dan dampak positif.

\section{Pengertian Kepuasan Konsumen}

Menurut Amir (2005), kepuasan konsumen adalah sejauhmana manfaat produk dirasakan sesuai dengan yang diharapkan konsumen. Sedangkan menurut Aritonang (2005) kepuasan sebagai hasil penilaian konsumen terhadap apa yang diharapkannya dengan membeli dan mengkonsumsi produk. Kepuasan adalah perasaan senang atau kecewa seseorang yang muncul setelah membandingkan antara persepsi atau kesannya terhadap kinerja (atau hasil) suatu produk dan harapan-harapannya (Kotler, 2005).

\section{Pengukuran Kepuasan Konsumen}

Lupiyoadi dan Hamdani (2008) menyatakan bahwa ada beberapa aspek dalam mengetahui kepuasan konsumen, sebagai berikut:

1. Memperkecil kesenjangan yang terjadi antara pihak manajemen dan konsumen

2. Perusahaan harus mampu membangun komitmen bersama untuk menciptakan visi didalam perbaikan proses pelayanan

3. Memberi kesempatan kepada konsumen untuk menyampaikan keluhan

4. Mengembangkan dan menerapkan accountable, proactive, dan partnership marketing sesuai dengan situasi pemasaran

Menurut Kotler (2005:102), ada empat (4) metode yang digunakan dalam pengukuran kepuasan konsumen adalah sebagai berikut:

1. Sistem keluhan dan saran

Organisasi yang berpusat konsumen memberikan kesempatan yang luas kepada para konsumennya untuk menyampaikan saran dan keluhan, misalnya dengan menyediakan

orang berperan atau bersikap sebagai konsumen potensial produk perusahaan dan pesaing. Kemudian mereka melaporkan mengenai kekuatan dan kelemahan produk perusahaan dan pesaing berdasar pengalaman mereka dalam pembelian produk tersebut.

2. Lost customer analysis

Metode ini dilakukan Perusahaan dengan cara sebaiknya menghubungi konsumen yang telah berhenti membeli atau yang telah pindah pemasok agar dapat memahami mengapa hal itu terjadi dan mengambil kebijakan perbaikan selanjutnya. Bukan hanya exit interview saja yang perlu, tetapi pemantauan customer loss rate juga penting, dimana peningkatan customer loss rate menunjukkan kegagalan perusahaan dalam memuaskan konsumen.

3. Survei kepuasan konsumen

Sesekali perusahaan perlu melakukan survey kepuasan konsumen terhadap kualitas jasa atau produk perusahaan tersebut. Survey ini dapat dilakukan dengan penyebaran kuesioner oleh karyawan perusahaan kepada para konsumen. Melalui survey tersebut, perusahaan dapat mengetahui kekurangan dan kelebihan produk atau jasa perusahaan tersebut, sehingga perusahaan dapat melakukan perbaikan pada hal yang dianggap kurang oleh konsumen.

\section{Faktor-faktor yang Mempengaruhi Kepuasan Konsumen}

Faktor-faktor yang mempengaruhi persepsi dan harapan konsumen menurut Gasperz (2005) yaitu:

1. Kebutuhan dan keinginan yang berkaitan dengan hal-hal yang dirasakan konsumen ketika konsumen sedang mencoba melakukan transaksi dengan produsen atau pemasok produk (perusahaan). Jika pada saat itu kebutuhan dan keinginan besar, harapan atau ekspetasi konsumen akan tinggi, demikian pula sebaliknya.

2. Pengalaman masa lalu ketika mengkonsumsi produk dari perusahaan maupun pesaing-pesaingnya. Perusahaan tersebut harus memberikan manfaat yang sesuai dengan apa yang dibutuhkan oleh konsumennya. 
3. Pengalaman dari teman-teman, dimana mereka akan menceritakan kualitas produk yang akan dibeli oleh konsumen. Hal itu jelas mempengaruhi persepsi konsumen terutama pada produk-produk yang dirasakan berisiko tinggi.

\section{Hipotesis}

Berdasarkan landasan teori dan penelitian sebelumnya, hipotesis yang digunakan dalam penelitian ini adalah:

1. Kualitas pelayanan (bukti fisik, keandalan, daya tanggap, jaminan dan perhatian) secara parsial berpengaruh signifikan terhadap kepuasan konsumen pada depot air minum isi ulang Tirta Tamiang di Kecamatan Tenggulun.

2. Kualitas pelayanan (bukti fisik, keandalan, daya tanggap, jaminan dan perhatian) secara simultan berpengaruh signifikan terhadap kepuasan konsumen pada depot air minum isi ulang Tirta Tamiang di Kecamatan Tenggulun.

\section{METODE PENELITIAN}

\section{Jenis dan Sumber Data}

Jenis data yang digunakan pada penelitian ini adalah:

1. Data kualitatif adalah data yang berupa karakteristik kategori atau ciri khas suatu objek penelitian (Sunyoto, 2012). Data kualitatif pada penelitian ini berupa gambaran secara umum depot air minum isi ulang Tirta Tamiang Dusun Sumberejo Kecamatan Tenggulun.

2. Data kuantitatif adalah data yang berupa angka-angka atau bilangan baik utuh maupun tidak utuh (Sunyoto, 2012). Data kuantitatif pada penelitian ini adalah jumlah responden serta hasil kuesioner yang disebarkan kepada responden.

Sumber data dalam penelitian ini dibagi menjadi dua sumber, yaitu:

1. Data primer adalah data asli yang dikumpulkan oleh periset untuk menjawab masalah riset secara khusus (Sunyoto, 2012). Data primer yang digunakan dalam penelitian ini melalui wawancara, observasi dan hasil pengisian kuesioner oleh responden yaitu konsumen depot air minum isi ulang Tirta Tamiang.
2. Data sekunder merupakan data yang telah dikumpulkan oleh pihak lain, bukan oleh periset sendiri (Sunyoto, 2012). Data sekunder diperoleh dari berbagai bahan pustaka, baik berupa buku,jurnal dan skripsi.

\section{Populasi dan Sampel}

Populasi adalah wilayah generalisasi yang terdiri dari obyek/subyek yang mempunyai kualitas dan karakteristik tertentu yang ditetapkan oleh peneliti untuk dipelajari dan kemudian ditarik kesimpulannya (Sugiyono, 2010). Populasi dalam penelitian ini adalah konsumen air isi ulang berdasarkan catatan pihak depot air minum isi ulang Tirta Tamiang dari Januari 2016 sampai Desember 2016 yang jumlahnya 936 konsumen. Kemudian diambil sampel dengan teknik simple random sampling atau penentuan sampel acak sederhana yaitu memberikan kesempatan pada setiap anggota populasi untuk menjadi sampel. Jumlah sampel dalam penelitian ini ditentukan dengan rumus slovin (Umar, 2005) yaitu:

$$
\frac{N}{1+N\left(e^{2}\right)}
$$

Keterangan:

$$
\begin{array}{ll}
\mathrm{n} & =\text { Ukuran sampel } \\
\mathrm{N} & =\text { Ukuran populasi } \\
\mathrm{e} & =\text { Nilai kritis (toleransi kesalahan } \\
& 10 \% \text { ) }
\end{array}
$$

Berdasarkan rumus di atas maka sampel yang diperoleh yaitu:

$$
\begin{aligned}
n & =\frac{936}{1+936\left(0,1^{2}\right)} \\
& =\frac{936}{1+9,36} \\
& =\frac{936}{10,36}=90,34749
\end{aligned}
$$

\section{dibulatkan menjadi 90 orang sampel}

\section{Metode Analisis Data}

Metode analisis data adalah metode yang digunakan untuk mengolah hasil penelitian guna memperoleh kesimpulan. Dalam penelian ini analisis data yang 
dipergunakan adalah analisis data kuantitatif, dengan menggunakan perhitungan persamaan regresi berganda yang dikemukakan oleh Sunyoto (2012):

$$
\mathrm{Y}=\mathrm{a}+\mathrm{b}_{1} \mathrm{X}_{1}+\mathrm{b}_{2} \mathrm{X}_{2}+\mathrm{b}_{3} \mathrm{X}_{3}+\ldots .+\mathrm{b}_{\mathrm{n}} \mathrm{X}_{\mathrm{n}}
$$

\section{Keterangan:}

$\mathrm{Y}=$ Subyek dalam variabel dependen yang diprediksikan

$\mathrm{X}=$ Subyek pada variabel independen yang mempunyai nilai tertentu

$\mathrm{a}=$ Harga $\mathrm{Y}$ bila $\mathrm{X}=0$ (harga konstanta)

$\mathrm{b}=$ Angka arah atau koefisien regresi, yang menunjukkan angka peningkatan ataupun penurunan variabel dependen yang didasarkan pada variabel independen.

$b_{n}=$ jumlah koefisien regresi penelitian

$X_{\mathrm{n}}=$ jumlah variabel penelitian

Rumus tersebut dimodifikasi sesuai dengan variabel penelitian ini:

$\mathrm{KK}=\mathrm{a}+\mathrm{b}_{1} \mathrm{BF}+\mathrm{b}_{2} \mathrm{~K}+\mathrm{b}_{3} \mathrm{DT}+\mathrm{b}_{4} \mathrm{~J}+\mathrm{b}_{5} \mathrm{P}$

Keterangan:

$\mathrm{KK}=$ Kepuasan Konsumen

$\mathrm{BF}=$ Bukti Fisik

$\mathrm{K}$ = Kehandalan

DT = Daya Tanggap

$\mathrm{J}=$ Jaminan

$\mathrm{P} \quad=$ Perhatian

$\mathrm{a} \quad=$ Konstanta

$b_{1} \ldots b_{5},=$ Nilai Koefisien Regresi

Untuk membuktikan hipotesis dalam penelitian ini digunakan uji $\mathrm{t}$ dan uji $\mathrm{F}$, sebagai berikut:

\section{Uji t (uji parsial)}

Pengujian parsial digunakan untuk membuktikan apakah terdapat pengaruh antara kualitas layanan (bukti fisik, kehandalan, daya tanggap, jaminan dan perhatian) terhadap kepuasan konsumen:

$\mathrm{H}_{0}: \beta_{\mathrm{i}}=0$, artinya secara parsial terdapat pengaruh tidak signifikan dari kualitas layanan (bukti fisik, keandalan, daya tanggap, jaminan dan perhatian) terhadap kepuasan konsumen.
$\mathrm{H}_{\mathrm{a}}: \beta_{\mathrm{i}} \neq 0$, artinya secara parsial terdapat pengaruh signifikan dari kualitas layanan (bukti fisik, keandalan, daya tanggap, jaminan dan perhatian) terhadap kepuasan konsumen.

Kriteria pengambilan keputusan:

$\mathrm{H}_{0}$ diterima atau $\mathrm{H}_{\mathrm{a}}$ ditolak, jika $\mathrm{t} \operatorname{sig}<\alpha=$ $5 \%$

$\mathrm{H}_{0}$ ditolak atau $\mathrm{H}_{\mathrm{a}}$ diterima, jika $\mathrm{t} \operatorname{sig}>\alpha=$ $5 \%$

2. Uji F (uji simultan)

Pengujian simultan (uji F) digunakan untuk menguji pengaruh secara bersama-sama terdapat pengaruh antara kualitas layanan (bukti fisik, keandalan, daya tanggap, jaminan dan perhatian) terhadap kepuasan konsumen:

$\mathrm{H}_{0}: \beta_{\mathrm{i}}=0$, artinya secara bersama-sama terdapat pengaruh tidak signifikan dari kualitas layanan (bukti fisik, keandalan, daya tanggap, jaminan dan perhatian) terhadap kepuasan konsumen.

$\mathrm{H}_{\mathrm{a}}: \beta_{\mathrm{i}} \neq 0$, artinya secara bersama-sama terdapat pengaruh signifikan dari kualitas layanan (bukti fisik, keandalan, daya tanggap, jaminan dan perhatian) terhadap kepuasan konsumen.

Kriteria pengambilan keputusan:

$\mathrm{H}_{0}$ diterima atau $\mathrm{H}_{\mathrm{a}}$ ditolak, jika $\mathrm{F}$ sig $<\alpha$ $=5 \%$

$\mathrm{H}_{0}$ ditolak atau $\mathrm{H}_{\mathrm{a}}$ diterima, jika $\mathrm{F}$ sig $>\alpha$ $=5 \%$

3. Koefisien Determinasi (Adjusted $\mathrm{R}^{2}$ )

Adjusted $\mathrm{R}^{2}$ digunakan untuk mengukur seberapa jauh kemampuan variabelvariabel bebas dalam menerangkan variasi variabel terikat. Koefisien determinasi berkisar antara 0 sampai dengan $1\left(0 \leq \mathrm{R}^{2}\right.$ $\leq 1$ ), dimana semakin tinggi $\mathrm{R}^{2}$ (mendekati 1) berarti variabel-variabel bebas memberikan semua informasi yang dibutuhkan untuk memprediksi variasi variabel terikat dan apabila Adjusted $\mathrm{R}^{2}=$ 0 menunjukkan variabel bebas keseluruhan tidak dapat menjelaskan variabel terikat. 


\section{HASIL ANALISIS}

Pengaruh Kualitas Pelayanan terhadap Kepuasan Konsumen pada Depot Air Minum Isi Ulang Tirta Tamaing

Tabel 1 merupakan hasil analisis regresi linier berganda yang pengolahan datanya menggunakan SPSS.

Model regresi linier dari Tabel di atas yaitu $\mathrm{KK}=2,193+0,065 \mathrm{BF}+0,166 \mathrm{~K}+$ $0,032 \mathrm{DT}+0,075 \mathrm{~J}+0,164 \mathrm{E}$. adalah:

Interpretasi dari persamaan tersebut

1. Berdasarkan persamaan regresi diketahui nilai konstanta yaitu 2,193 yang berarti jika bukti fisik, keandalan, daya tanggap, jaminan, dan empati bernilai tetap maka nilai kepuasan konsumen yaitu 2,193.

2. Nilai koefisien regresi bukti fisik 0,065 mempunyai pengaruh positif yang berarti jika bukti fisik meningkat satu satuan maka kepuasan konsumen akan meningkat sebesar 0,065 satuan dengan asumsi variabel bebas lainnya tidak berubah.

3. Nilai koefisien regresi keandalan 0,166 mempunyai pengaruh positif yang berarti jika keandalan meningkat satu satuan maka kepuasan konsumen akan meningkat sebesar 0,166 satuan dengan asumsi variabel bebas lainnya tidak berubah.

4. Nilai koefisien regresi daya tanggap 0,032 mempunyai pengaruh positif yang berarti jika daya tanggap meningkat satu satuan maka kepuasan konsumen akan meningkat sebesar 0,032 satuan dengan asumsi variabel bebas lainnya tidak berubah.
5. Nilai koefisien regresi jaminan 0,075 mempunyai pengaruh positif yang berarti jika jaminan meningkat satu satuan maka kepuasan konsumen akan meningkat sebesar 0,075 satuan dengan asumsi variabel bebas lainnya tidak berubah.

6. Nilai koefisien regresi empati 0,164 mempunyai pengaruh positif yang berarti jika empati meningkat satu satuan maka kepuasan konsumen akan meningkat sebesar 0,164 satuan dengan asumsi variabel bebas lainnya tidak berubah.

Berdasarkan Tabel 1 diketahui nilai Adjusted R Square yaitu 0,219. Artinya, bukti fisik, keandalan, daya tanggap, jaminan, dan empati mempengaruhi kepuasan konsumen pada depot air minum isi ulang Tirta Tamiang sebesar $21,9 \%$, sedangkan sisanya $78,1 \%$ dipengaruhi oleh variabel lain yang tidak diteliti dalam penelitian ini.

\section{Pembuktian Hipotesis}

1. Hasil Uji $\mathrm{t}$

Dengan melihat Tabel 1 pada kolom sig, maka hasil uji t dapat dijelaskan sebagai berikut.
a. Bukti fisik berpengaruh tidak signifikan terhadap kepuasan konsumen dikarenakan nilai signifikansi variabel bukti fisik 0,510 lebih besar dari 0,05.
b. Keandalan berpengaruh tidak signifikan terhadap kepuasan konsumen dikarenakan nilai signifikansi variabel keandalan 0,092 lebih besar dari 0,05.

Tabel 1. Hasil Analisis Statistik

\begin{tabular}{|c|c|c|c|}
\hline Variabel & $\mathrm{B}$ & $\mathrm{T}$ & Sig. $\mathrm{t}$ \\
\hline Konstanta & 2,193 & 2,515 & ,014 \\
\hline Bukti Fisik &, 065 & ,661 & ,510 \\
\hline Keandalan & , 166 & 1,702 & ,092 \\
\hline Daya Tanggap & 032 & ,338 & ,736 \\
\hline Jaminan &, 075 & ,707 & .482 \\
\hline Empati & ,164 & 1,428 &, 157 \\
\hline Adjusted R Square & ,219 & & \\
\hline $\mathrm{F}$ & 1,377 & & \\
\hline Sig. F &, 257 & & \\
\hline
\end{tabular}

Sumber: Data Primer diolah, 2017 
c. Daya tanggap berpengaruh tidak signifikan terhadap kepuasan konsumen dikarenakan nilai signifikansi variabel daya tanggap 0,736 lebih besar dari 0,05 .

d. Jaminan berpengaruh tidak signifikan terhadap kepuasan konsumen dikarenakan nilai signifikansi variabel jaminan 0,0482 lebih besar dari 0,05.

e. Empati berpengaruh tidak signifikan terhadap kepuasan konsumen dikarenakan nilai signifikansi variabel empati 0,157 lebih besar dari 0,05.

Dari hasill uji parsial maka dapat dinyatakan bahwa bukti fisik, keandalan, daya tanggap, jaminan, dan empati secara parsial berpengaruh tidak signifikan terhadap kepuasan konsumen pada depot air minum isi ulang Tirta Tamiang, sehingga hipotesis ditolak.

\section{Hasil Uji F}

Tabel 1 menjelaskan bahwa nilai $\mathrm{F}$ signifikan adalah 0,257 atau lebih besar dari 0,05 . Oleh karena itu dapat dinyatakan bahwa bukti fisik, keandalan, daya tanggap, jaminan, dan empati secara bersama-sama berpengaruh tidak signifikan terhadap kepuasan konsumen pada depot air minum isi ulang Tirta Tamiang.

Dengan demikian maka dapat dinyatakan bahwa hipotesis dalam penelitian ini ditolak.

\section{Pembahasan}

Kualitas pelayanan menjadi tuntutan penting dalam persaingan tingkat global, industri dan perusahaan. Tingkat kualitas dinilai berdasarkan sudut pandang konsumen. Untuk menciptakan kualitas layanan tinggi, perusahaan harus menawarkan layanan yang mampu diterima konsumen sesuai atau melebihi harapan konsumen. Dengan adanya kualitas pelayanan yang baik konsumen akan merasa puas dan akan terus melakukan pembelian ulang.

Berdasarkan analisis data dapat dijelaskan bahwa kualitas pelayanan yang meliputi bukti fisik, keandalan, daya tanggap, jaminan dan empati secara parsial maupun simultan berpengaruh tidak signifikan terhadap kepuasan konsumen pada depot air minum isi ulang Tirta Tamiang di Kecamatan Tenggulun. Hal ini menunjukkan bahwa pembelian yang dilakukan oleh konsumen tidak terlepas dari kebutuhan vital manusia terhadap air minum sehingga pelayanan yang baik tidak menjamin meningkatnya pembelian konsumen, namun karena kebutuhan terhadap air minum tersebutlah yang menciptakan pembelian pada air minum isi ulang Tirta Tamiang di Kecamatan Tenggulun.

\section{KESIMPULAN DAN SARAN Kesimpulan}

Kesimpulan yang dapat ditarik dari hasil analisis data yaitu:

1. Model regesi yang diperoleh dari analisis data yaitu $\mathrm{KK}=2,193+0,065 \mathrm{BF}+$ $0,166 \mathrm{~K}+0,032 \mathrm{DT}+0,075 \mathrm{~J}+0,164 \mathrm{E}$. Berdasarkan persamaan regresi diketahui nilai konstanta yaitu 2,193 yang berarti jika bukti fisik, keandalan, daya tanggap, jaminan, dan empati bernilai tetap maka nilai kepuasan konsumen yaitu 2,193. Nilai koefisien regresi bukti fisik mempunyai pengaruh positif sebesar 0,065 satuan. Nilai koefisien regresi keandalan mempunyai pengaruh positif sebesar 0,166 satuan. Nilai koefisien regresi daya tanggap mempunyai pengaruh positif sebesar 0,032 satuan. Nilai koefisien regresi jaminan mempunyai pengaruh positif sebesar 0,075 satuan. Nilai koefisien regresi empati mempunyai pengaruh positif sebesar 0,164 satuan.

2. Bukti fisik, keandalan, daya tanggap, jaminan, dan empati mempengaruhi kepuasan konsumen pada depot air minum isi ulang Tirta Tamiang sebesar 21,9\%, sedangkan sisanya $78,1 \%$ dipengaruhi oleh variabel lain yang tidak diteliti dalam penelitian ini.

3. Bukti fisik, keandalan, daya tanggap, jaminan dan empati secara parsial menunjukkan pengaruh yang tidak signifikan terhadap kepuasan konsumen pada depot air minum isi ulang Tirta Tamiang dikarenakan nilai signifikansi 
masing-masing variabel bebas lebih besar dari 0,05 .

4. Bukti fisik, keandalan, daya tanggap, jaminan dan empati secara bersama-sama menunjukkan pengaruh yang tidak signifikan terhadap kepuasan konsumen pada depot air minum isi ulang Tirta Tamiang dikarenakan nilai $\mathrm{F}$ sig. lebih besar dari 0,05 .

\section{Saran}

Dari kesimpulan di atas maka saran yang dapat diberikan yaitu:

1. Karyawan depot air minum Tirta Tamiang harus cepat dan tanggap dalam merespon dan mengantar pesanaan konsumen.

2. Pemilik depot air minum Tirta Tamiang harus secara konsisten memberikan kupon untuk setiap kali pembelian konsumen agar konsumen tidak berpaling ke depot air minum lain.

3. Peralatan-peralatan yang digunakan harus selalu dibersihkan agar pada saat air minum diantar ke konsumen, tidak ditemukan kotoran-kotoran yang menempel pada galon maupun isinya.

\section{DAFTAR PUSTAKA}

Amir, M. Taufiq. 2005. Dinamika Pemasaran: Jelajahi dan Rasakan. Jakarta: Raja Grafindo Persada.

Aritonang, L.R. 2005. Kepuasan Pelanggan

Pengukuran dan Penganalisisan dengan SPSS. Jakarta: PT. Gramedia Pustaka Utama.

Ferdinand. Augusty. 2006. Metode

Penelitian Manajemen: Pedoman Penelitian untuk Penulisan Skripsi, Tesis, dan Disertasi Ilmu Manajemen. Semarang: BP Universitas Diponegoro.
Gasperz, Vincent. 2005. Total Quality Management. Jakarta: PT. Gramedia Pustaka Utama.

Hardiyati, Ratih. 2010. Aanalisis Pengaruh Kualitas Pelayanan terhadap Kepuasan Konsumen Menggunakan Jasa Penginapan (Villa) Agrowisata Kebun Teh Pagilaran. Skripsi. Fakultas Ekonomi, Universitas Diponegoro Semarang.

Kotler, Philip. 2005. Manajemen Pemasaran, Analisis Perencanaan, Implementasi dan Pengendalian. Jakarta: PT. Erlangga.

Lupiyoadi, Rambat. 2006. Pelayanan Prima. Jakarta: Gramedia.

dan Hamdani. 2008.

Manajemen Pemasaran Jasa. Jakarta:

Salemba Empat.

Manullang, Ida. 2008. Pengaruh Kualitas Pelayanan terhadap Kepuasan

Pelanggan Jasa Penerbangan PT. Garuda Indonesia Airlines di Bandara Polonia Medan. Skripsi (dipublikasikan). Universitas Sumatera Utara. Medan.

Nasution. M. Nur. 2004. Manajemen Jasa Terpadu. Bogor: Ghalia Indonesia.

Sugiyono. 2010. Metedologi Penelitian Bisnis. Bandung: Alfabeta.

Sunyoto, Danang. 2012. Konsep Dasar Riset Pemasaran \& Perilaku Konsumen. Yogyakarta: CAPS.

Tjiptono. Fandy dan Gregorius Chandra. 2005. Service Quality Satisfaction. Yogyakarta: Andi

2009. Perspektif

Manajemen dan Pemasaran

Kontemporer. Yogyakarta: Andi.

Umar, Husen. 2005. Riset Pemasaran dan Perilaku Konsumen. Jakarta: Gramedia Pustaka Utama. 